\title{
Corporate Governance and Service Delivery in Healthcare. A Case of Gaborone Private Hospital
}

\author{
Article by Emuron Joseph \\ Management, Texila American University \\ E-mail:emuronj@yahoo.com
}

\begin{abstract}
This study was aimed at establishing the role of corporate governance and service delivery in healthcare in Botswana by looking at the case of Gaborone Private Hospital. The study was guided by the following questions: What are the effects of corporate planning in clinical governance in healthcare service delivery? What is the role of corporate social responsibility in HIV/AIDS mitigation in healthcare service delivery? What are the effects of corporate communication in clinical governance and service delivery in healthcare? The study used a purposive sampling technique as it was important to identify people with a certain kind of knowledge that would give the required information. The data collecting tool was a closed-ended questionnaire, and this data was analyzed thematically using Statistical Package for Social Scientists (SPSS) version 16.0 where both descriptive statistics and Analysis of Variance (ANOVA - One Way) were used. The P-value was parked at .005 to define level of significance; the results from ANOVA revealed in general that all themes were not statistically significant meaning that corporate governance in health service is heavily affected by service delivery approaches;
\end{abstract}

Keywords: Service delivery; HIV/AIDS; Botswana; Gaborone Private Hospital.

\section{Introduction}

Corporate governance is a system of management which defines the relationship between the top management, the board of directors and the shareholders. It defines the power relationships between the keys stakeholders as well as the power and control mechanism meant to achieve desired outcome (Youssef, 1991). Corporate governance cuts across the spectrum as it applies to government enterprises, family business or any other venture. Implementing corporate governance principles can enhance performance, stream line the organizational objectives as well as reduce or eliminate wastage, reduce corruption, enhance business confidence, improve the image of the business entity, among others (Youssef, 1991). Corporate governance is based on certain principles which are: responsibility, accountability, fairness and transparency and these principles are universal across the environments (Magdi, Iskander and Chamlou, 2000).

Corporate governance involves a variety of stakeholders that should command influences in management and operation of programs and include: government agencies and authorities, stock exchanges, management (including the board of directors and its chair, the Chief Executive Officer or the equivalent, other executives and line management, shareholders and auditors. Other influential stakeholders may include lenders, suppliers, employees, creditors, customers and the community at large. (Raut, web). This definition rimes well with the stakeholders' theory in corporate governance.

Corporate governance can be traced back to centuries after culmination of blunder, systematic failure and crises dating back to 1700s in South Sea Bubble. During the time 1970, England experienced crises in the banking sector that resulted in the development of new way of thinking, new laws and new practices to harmonize the management challenges at the time. In 1929, USA also experienced crushes in the stock market; savings and loan debacle in the 1980s. There was also a failure by the Maxwell Group raid on the pension fund of the Mirror Group of newspapers; there was the collapse of the Bank of Credit and Commerce International and Barrings Bank (The World Bank, 2000). During the 1980s, some member states of the Organization for Economic Co-operation and Development (OECD) countries notably Switzerland and Australia encountered challenges as evidenced by scandals in the management of corporations such as exorbitant salaries to the top brass 
of management; poor recruitment policies based on favoritism, lack of strategic planning heightened the ante that eventually saw declining performances within business enterprises (L'huillier, 2014).

Then about two decades ago, corporate governance had been adopted as a new concept of the postCold war economic architecture. In 1998, Asia experienced a financial crisis and defaulted on Russian debt so the leaders of the Great seven (G7) nations decided to take on a new perspective on management spheres so as to tackle the existential problem at that time such that by the mid-1999, the Organization for Economic Cooperation and Development (OECD) came up with new principles to propel development to greater height. At the time, even International Finance Institutions agreed that the only to achieve growth was to change the management practices, introduce new regulations and culture hence corporate governance (Berg, 2003). In Ireland, the enactment of government codes and reforms such as The Cadbury Report and Higgs Report resulted into its emergency as a vibrant concept that could alter the basic management paradigm to fit into better management practice. The evolution continued when the World Bank received and appreciated the concept as a tool that could result into some form of sustainable development.

\section{General and specific objectives}

The general objective of the study is to establish the role of corporate governance and service delivery in healthcare.

\section{The objectives were:}

i. Examine effects of corporate planning in clinical governance and service delivery in healthcare.

ii. Assess the role of corporate social responsibility in HIV/AIDS mitigation in service delivery in healthcare.

iii. Examine the effect of corporate identity and clinical communication in service delivery in healthcare.

\section{Literature review}

The study was carried under the concept better health delivery service in the health care yields positive results on corporate governance being undertaken by an organization. The conceptual framework below depicts that if an organization is having well organized service delivery channels in health care services, the society and or the customers will acknowledge the company or organization's efforts in corporate governance. In the case of an organization failing to deliver service in a positive manner to the people, it consequently has a bad impact on the outcome of the company's efforts in corporate social responsibility. The society will fail to recognize or appreciate the corporate social responsibilities that an organization does when they even mess up in only one of the pivotal deliver services approaches as indicated by figure 2.1 below. 


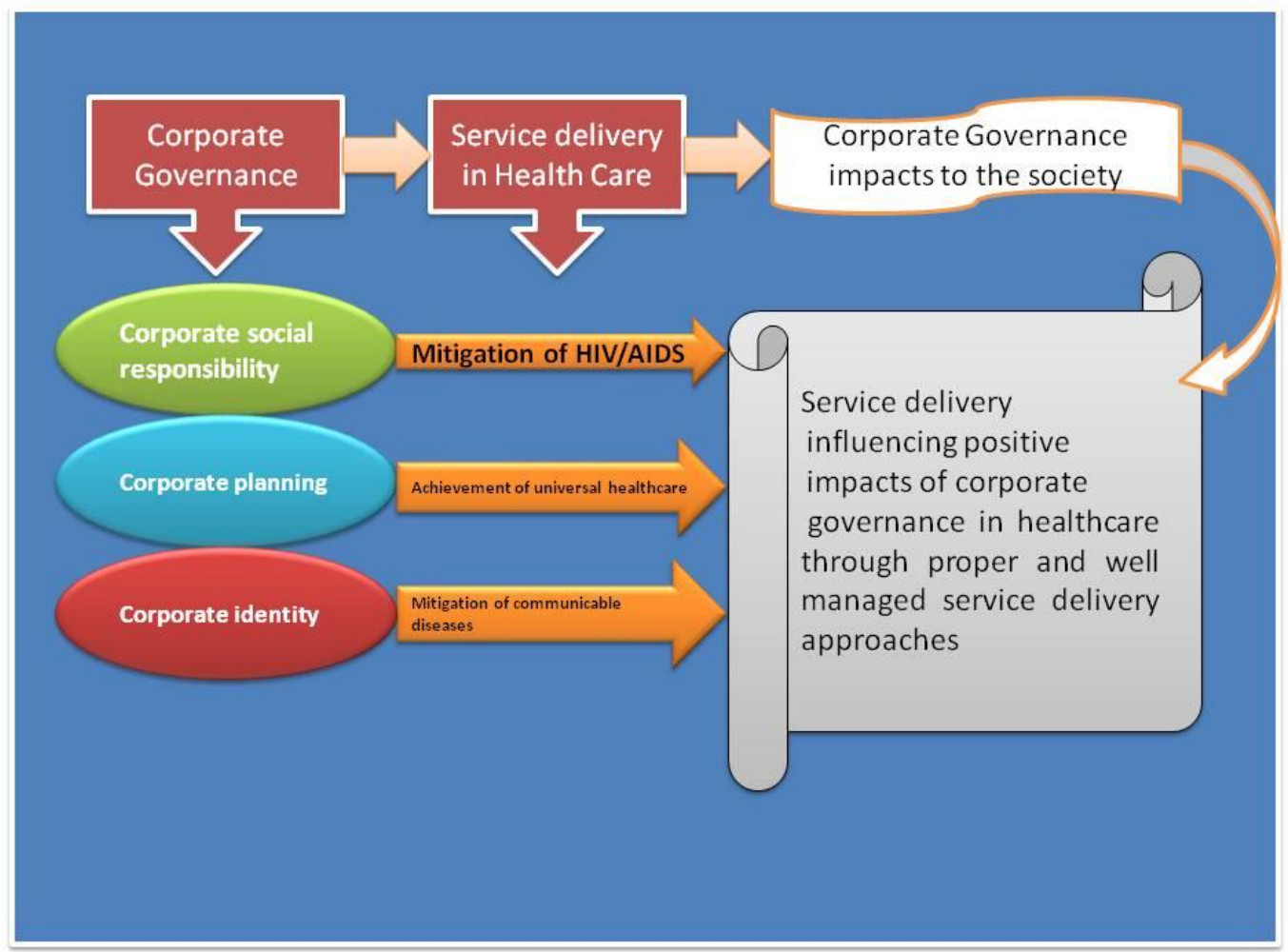

Figure. 2.1. Conceptual framework of the study

Source: Author, 2018

\section{Literature review according to objectives}

\section{Corporate planning in clinical governance and service delivery in healthcare}

Corporate planning forms a fabric of corporate governance. It entails having strategic plans aimed at ensuring best practices are adopted in the provision of services to the communities. Ironically, the healthcare system has to implement systematic programs that meet standards of a competitive healthcare system.

(Northern Devon Healthcare NHS Trust, 2010:4) defines clinical governance as "a framework through which NHS organizations are accountable for clinical performance, underpinning quality and continuous improvement. It exists to safeguard high standards of care, and provide an environment in which excellence can flourish.' Clinical governance measures the way in which organizations provide accountability to the stakeholders for the services they are providing. The basic principle is to ensure quality service is available at all people who will need and organizations should endeavor to continuously improve their services. The elements of clinical governance require that those in the leadership positions undertake initiatives to inculcate a culture where everyone is accountable to their actions, innovation and upgrading the system as the only way of realizing an effective and efficient delivery of services (Kilby, 2010-2013; Staniland, 2007). Quality assurance, customer improvement, performance management, continuous planning research and development, internal and external communications are some of the areas that have to be undertaken by the organizations when offering services to the communities. It ensures that the roles and responsibilities of the service providers are clear and manifest itself in the quality of healthcare the communities are receiving. Ideally, the overall responsibility to manage healthcare programs falls on the top management/chief executive who is the overseer of programs, monitors implementation at different levels to ensure they conform to the industry standards (Health Direct- Australia). For quality to prevail in the healthcare system, there is need for proper planning and coordination of activities, yet some managers are reluctant to plan. Lack of planning can distort the smooth arrangements that are aimed at guaranteeing the basic standards in the healthcare system. This is something of interest to discover in the healthcare organizations. 


\section{Corporate social responsibility in HIV/AIDS mitigation in service delivery in healthcare}

Corporate social responsibility, also sometimes called corporate responsibility, corporate ethics, corporate, corporate governance, corporate accountability, corporate citizenship as a concept has an elusive definition. Writers, academicians, etc., have different perspectives of understanding the meaning of the concept. However, generally, it can be defined as the undertakings that are pursued by the companies with the aim of realizing their intended goals as well as ensuring their activities have a positive impact on the environment. It covers aspects such as ethics, compliance with the law, and adherence to ethics; generally, it's just not about profit accumulation. The idea is businesses survive because of the people; hence the logical reasoning is that the people that make corporations survive and/or thrive should give back to the population or the people around (Cochran, 2007).

Corporate social responsibility as a concept has a history that dates back to the mid- $20^{\text {th }}$ century, especially from the mid 1950's and has evolved until today and it's important to note that some form of business concern for the society had existed dating back to the late 1800s. Eventually, corporations had to adapt to the business paradigms of the time as they sought for better ways of ensuring sustainability of resources that would cater for the current and future generations (Carrol, 2008). Staff welfare was also a key issue of concern that time because the workers wellbeing had to be addressed. It became a central focus issue during the industrial revolution when business owners were looking for better ways of improving productivity. Employers realized that in order to improve productivity, it required providing good working conditions to the workers, training them, better remunerations, etc.

There was a concern that the welfare of such vulnerable people was undermined and hence required proactive measures to deal with the situation that would later lead into provision of bath house, hospital clinics. Initially thought as philanthropic and a concept left to the big corporations alone, during the turn of the $20^{\text {th }}$ century, many companies including small ones adopted the concept and its application covers a wide range of areas such reduction in maternal health, reduction in mortality rate, contagious diseases, HIV/AIDS mitigation and management, environmental degradation, waste management (Cochran, 2007). In other words, it's a global phenomenon and its impact is far reaching.

The health rights organizations are up in arms campaigning for the consumer protection through formulation and strengthening of policies by local, national and international bodies. As a result, today most or almost all corporations have legitimized their operations to meet the standards of the regulating authorities (Crane, Matten, Laura and Spence, 2012). Organizations including the ones in the health sector should check their actions to ensure are in conformity with standards in a particular community. The concept has gained popularity in the sense that business leaders have taken it upon themselves to implement strategic plans geared towards the adoption of better operation strategies for the welfare of the workers and the society at large. Philanthropy is a word very much associated with CSR in the current era. Philanthropy has existed right from the early 1900s through institutions such as the Rockefeller foundation, builders of churches, endowers of educational institutions (Carrol, 2008).

Having its roots during the time of the industrial revolution the concept gained currency globally including in countries such India and Africa. From the early 2000, corporations have tended to make corporate social responsibility a component of strategic planning, strategic management, corporate governance and corporate image. The concept CSR has a large body of literature writings in USA because that is where it's believed it has its roots. However, Europe has also expanded in its understanding and involvements on CSR through conferences, research and other writings. This implies the concept has gained popularity across Europe. Not to be left behind, Asia and Africa joined the bandwagon by putting in place institutionalized policies and practices that would ensure successful utilization of the concept (Carrol, 2008).

In India, Tata Company has been known to provide charity donations to the communities for over hundred years. This is a sign that the new trend is just a climax of the old one as it's now incorporated in the company's strategic plans. (Crane, Matten and Spence, 2012). Looking at the trends in India, CSR spread around from the turn of the 21 centuries in the form of initiatives that are aimed at improving living standards such as in health-related areas, education, sustainability development. 
Most of the population in India leaves in the rural areas and that is an area which lags in terms of development such as poor schools, poor healthcare system, poor infrastructure and many other ills. It's because of this realization especially from governments' inability to provide service led the private sector to come and contribute towards the course of the underprivileged (P. Selvam, 2016). Considerable gains have been made since the concept application across the industry became widespread. Societal issues such as provision of clean drinking water, containment of contagious diseases, reduction in mortality diseases, should form part of what organizations value about humanity.

Africa is not far either, as the organization of the civil society is much stronger than before. A lot of awareness and information across the continent has made it possible for people to demand that the corporations should be mindful of their operations especially as pertains to health. It's also a moral kind of responsibility to give back to the community as well as taking care of the welfare of the people. Taking the case of Uganda, for instance, according to (Mukhaye, 2018), Kyambogo University rolls out free counseling services to neighbors after a realization that most of the students leave around the area hence whatever ills are being committed by the community members do affect the students. The community is infested a lot of drug addicts, child labor, smoking, prostitution, cancer related deaths, HIV/AIDS among others. In the words of the vice chancellor Kyambogo University, "Majority of people surrounding our university are young and drug addicts, do betting and also have a common problem of high HIV prevalence," Prof Katugunka said while launching the open day for guidance and counseling at the university main campus on Wednesday.

"These problems are also among our students, so we think that when we roll out the counseling services to the neighboring community and advise them to avoid such problems, we shall also address the same among our students," he added. Prof Katunguka said the guidance and counseling unit has already earmarked the necessary resources for the program.

Concurring with (Mukhaye, 2018), the Netherlands government is in partnership with the Ugandan government trade as a way of ensuring effective collaboration and sharing of goods and services and promotion of expertise. Dutch companies are expected to do business in a fair and honest manner so the recipients realize value for money. It's believed that the promotion of trade between the two communities will create a bond and long-term cooperation. By not cheating customers, by not selling expired/substandard goods, not charging high prices, the businesses are applying the societal aspects are observed as it will likely ensure proper wellbeing of the people (Royal Netherlands Embassy, (2016).

\section{Corporate identity and communication in service delivery in healthcare}

Corporate identity as a concept in management evolved around the 1970s and its impact has been felt until the present day. Corporate identity is a set of meanings by which an organization can be distinguished through its culture, communication, values, norms, etc. It also involves other aspects such as performance, the branding, and the structure that can be instrumental in its pursuit for success (Rutitisa, Batragab, Muiznieceb and Ritovsa, 2012). It means all ways in which the organization presents itself to the world, to the stakeholders and the way the stakeholders view it. This sounds a good attribute for an organization offering service to the community and having good image which is associated with having more customers/ patients and in turn more revenue coming in. When an organization builds a good image, it's believed to have the ability to attract commitment from the stakeholders towards its cause. Corporate identity helps communicate the programs the organization is pursuing or need to be pursued, in other words, it's a marketing tool that can help especially in competitive environments. Carter (1982, p. 5 as referenced by Melewar, Bassett and Simo es, web) defined the concept as "the logo or brand image of a company and all other visual manifestations of the identity of a company".

Corporate identity is a powerful tool when it comes to healthcare because people associate themselves with brands that they trust and are reliable; offer a high level of effectiveness. An organization should be in position to deliver on its promises and it's the method and the way services are delivered that can bring in more stakeholders, patients to seek services. This will send a powerful message to both internal and external stakeholders about the commitment that the organization has 
regarding service delivery. Organizations that undertake trainings, regular surveys about the perception of communities about its service delivery stand a chance to remain relevant to the changing needs of the population. Credibility is an important issue because it avails the organization the platform to influence policy at the local, national regional and international level (World Health Organization, Communication for Health). This gives a picture as to what is expected from organizations. But the picture may not be what is outside there as organizations are grappling with challenges such as mergers, deregulations, acquisitions, scope of activities that can undermine operations. It's pertinent to undertake studies to establish what actual prevails in organizations such as in the healthcare arena.

A strong corporate identity communicates good values about the organization as a mechanism of its contribution to the society including the workers. It sends a message to the employees about the commitment the employer has towards their cause and hence motivation to deliver more. Corporate identity is a marketing tool but the messages should be communication and information based as it's not ethical for hospitals to advertise their services to gain advantage against others. Managers should be seen as good communicators of the vision, values of the organizations. They need to address the aspects that cause change and reassure the stakeholders of their moral responsibilities so the stakeholders identify with them (Melewar et al. web). These are some of the essential undertakings the management has to take but it's often not the case because some organizations are interested at profit making at the expense of condition of workers and stakeholders. Organizations are believed to have challenges at various levels but the depth of some of these is something that is not clear. The kind of branding as it pertains to communication and how it translates to service delivery is something of importance as it can guide the way forward in-service delivery.

(Balmer and Gray, 2000 p.256), assert that "Conventional methods of redressing identity problems are becoming progressively less effective because, in our opinion, the traditional focus has viewed corporate identity and corporate communications as functional rather than as strategic. We suggest a much-broadened view that looks at corporate communications as a three-part system process primary, secondary, and tertiary. In many companies these three are out of balance. Primary communication should present a positive image of the company and set the stage for a strong reputation. Secondary communication should be designed to support and reinforce primary communication. Tertiary communications should be positive and result in a superior reputation if the other two stages of corporate communication are properly conceived. The authors postulate that senior managers who implement this can invest their organization with a competitive advantage".

\section{Methodology}

\section{Study area}

The study area is Gaborone Private Hospital. Gaborone private hospital is located in the south-east district of Botswana. It's a 132-bed hospital delivering healthcare services to community around Gaborone with total number of about 200 employees.

\section{Study population}

The study population was at Gaborone Private Hospital. There are two main private hospitals in Gaborone namely Gaborone Private Hospital popularly known as GPH and Bokamoso Private Hospital and together they are employing about five hundred workers. Gaborone Private Hospital (GPH) alone has about 200 workers. The management department makes up $20 \%$ of the total number of employees in the two hospitals.

\section{Study duration}

The research process started in August, 2018 until November 2018.

\section{Sampling method}

A purposive sampling technique was used in the study because it was important to identify people with a certain kind of knowledge that would give the required information. The researcher gave 
questionnaires to the management secretary who later on distributed them to the various members of staff.

\section{Sample size}

The sampling size of $15 \%$ of the total population was used. According to Gay (2000), a sample of $10 \%$ of accessible population is enough for a descriptive study. Of the total number of 200 workers, 30 participants took part in the study representing above the minimum of the recommended number of 20 according to Gay. This would compare to 30 participants if the study had taken place in Bokamoso Hospital which has a population of about 300 employees. This sample size is representative enough to give a clear picture of the corporate governance aspects in the private hospitals in Gaborone.

\section{Study tools to be used}

The study tools involved self-administered questionnaires which was closed ended type.

\section{Research instruments}

A cross-sectional study involving self-administered questionnaire interview was used to collect data.

\section{Pretesting}

Pre-testing research instrument was done to determine the validity of the questions. It helps to ascertain the relevance of the questions and as to whether they enlist the desired kind of response. The researcher then modified the research questions for easy understanding and response. It's one way of detecting if problems to the design of questionnaires exist or not so modifications can be made (Hilton, 2015). The pre-testing was done with twelve participants in a focus group discussion; their views were solicited to help modify the questions, six male and six female lecturers $(\mathrm{N}=12)$ in Gaborone University College of Law and Professional studies were recruited for the exercise. Participants ranged between the ages 27-40. The participants were asked questions on corporate governance and service delivery in healthcare. The responses helped improve the questionnaire.

\section{Data collection procedures}

The researcher sought permission from the relevant authorities in the hospital. There after submitted the questionnaires to the secretary management who later on circulated them to the respondents.

\section{Data analysis}

Data analysis is the process of editing and reducing accumulated data to a manageable size, developing summaries, looking for the patterns and applying statistical techniques (BOCODOL 2008 p. 223). Data from the structured questionnaires was coded and captured in an electronic database using software program for social scientists (SPSS) version 16.0. The researcher used SPSS 16.0 to perform descriptive statistics. Descriptive frequencies were presented through tables' and graphs. The responses given to each question were expressed as percentages of the total sample. Again, a clear overview was given through one way-Analysis of Variance (ANOVA), which was performed at $95 \%$ confidence level and using least significant difference (LSD) test with probability value of .005.

\section{Ethical consideration}

Ethical considerations in research are critical. Ethics are norms or standards for conduct that distinguish between right and wrong. They help to determine the difference between acceptable and unacceptable behaviours. Ethical standards prevent against the fabrication or falsifying of data and therefore, promote the pursuit of knowledge and truth which is the primary goal of research. (https://cirt.gcu.edu).

Ethical considerations can be specified as one of the most important parts of the research, dissertations may be doomed to failure if this part is missing and according to Bryman \& Bell (2007) the following points represent the most principles related to ethical considerations in dissertations:

- Research participants should not be subjected to harm in any ways whatsoever 
- Full consent should be obtained from participants prior to the study

- The protection of the privacy of research participants has to be ensured

- Adequate level of confidentiality of research data should be ensured

All these ethical considerations were taken into account during data collection, data analysis as well as post study period.

\section{Data analysis, discussion, interpretation and data presentation}

\section{Main findings}

The qualitative and quantitative findings are presented under the subsections of the research objectives.

Research objective 1: Examine effects of corporate planning in clinical governance and service delivery in healthcare.
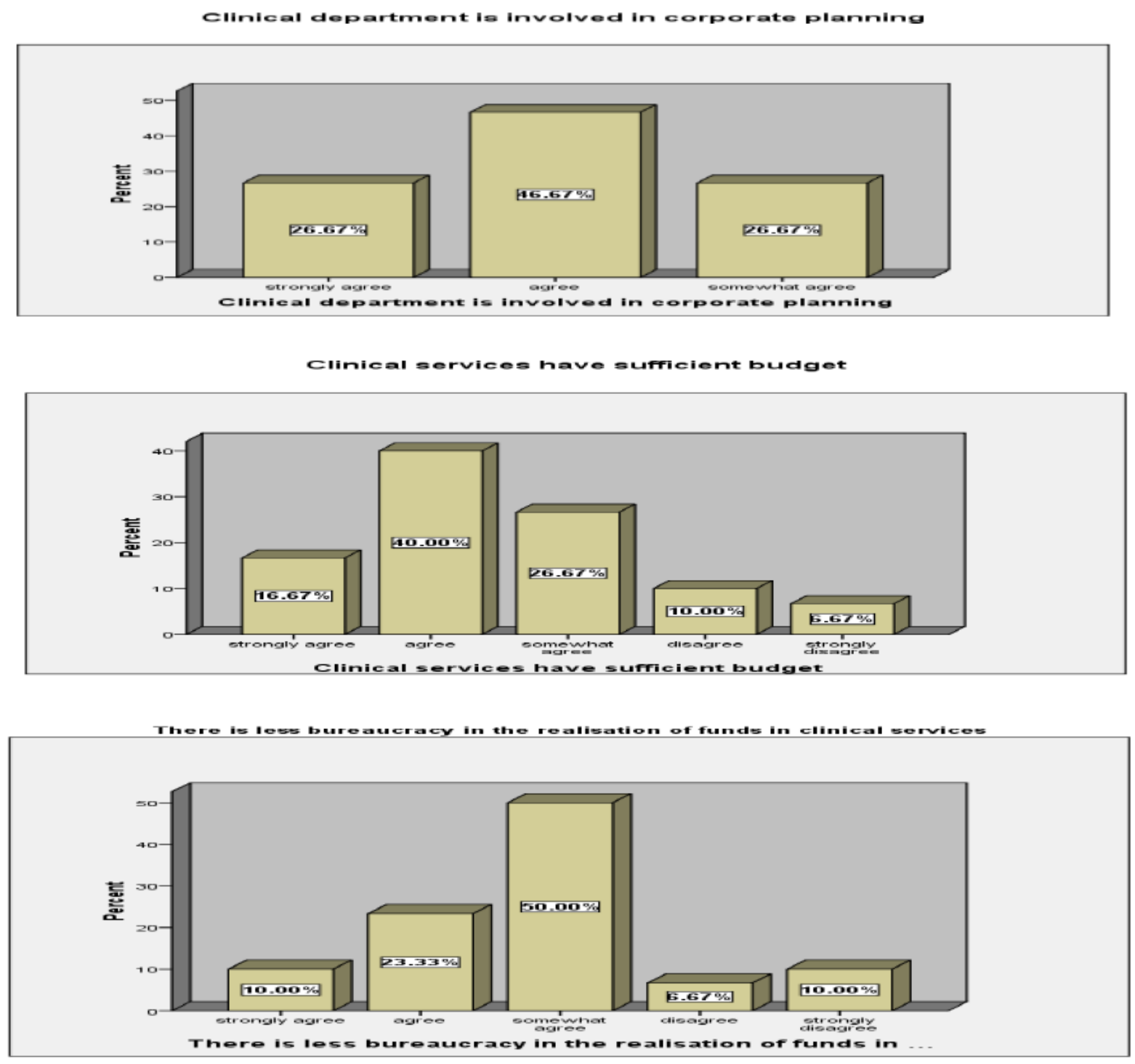
Clinical officers are represented in board of governors meetings

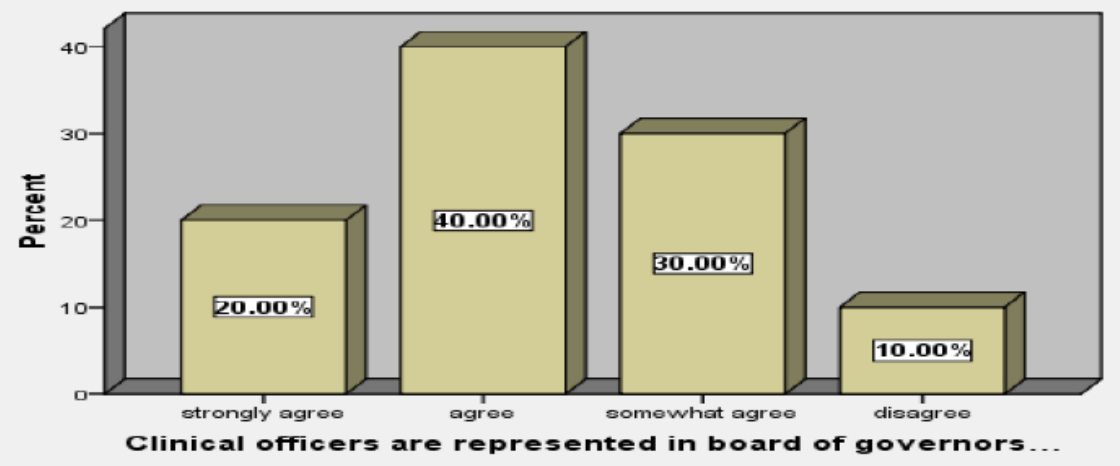

The board of management reviews ratio and clinicians to patients regularly

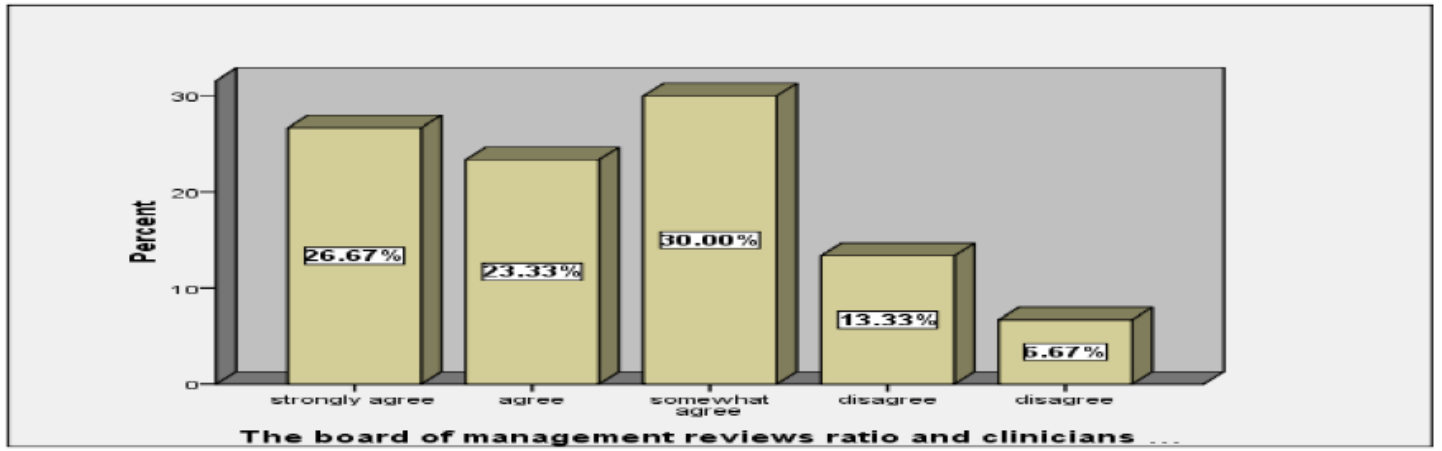

Research objective 2: Assess the role of corporate social responsibility in HIV/AIDS mitigation in service delivery in healthcare

The hospital has been in the fore front of HIV mitigation

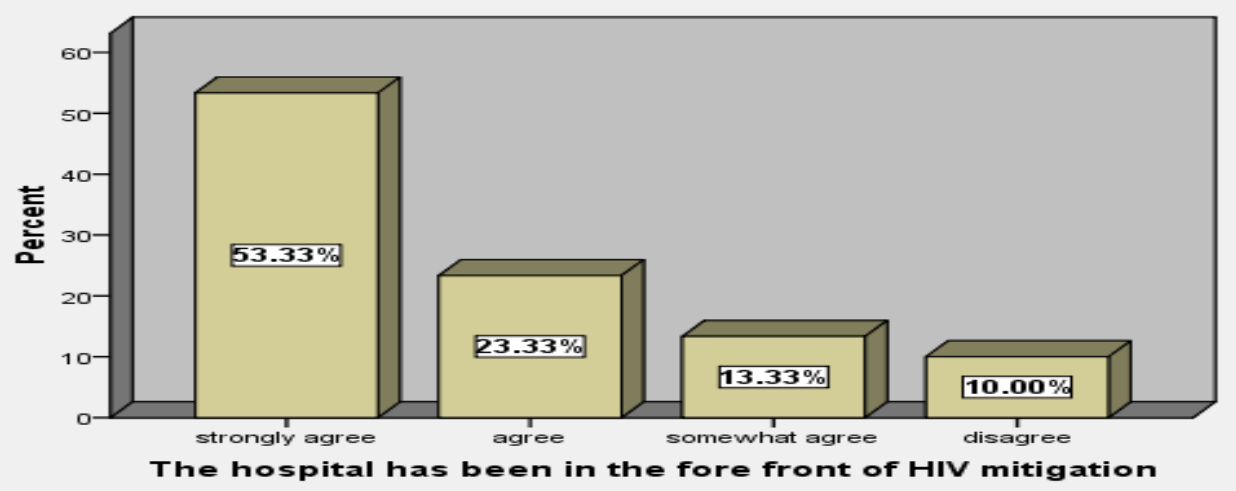




\section{Environmental sustainability policy is active}

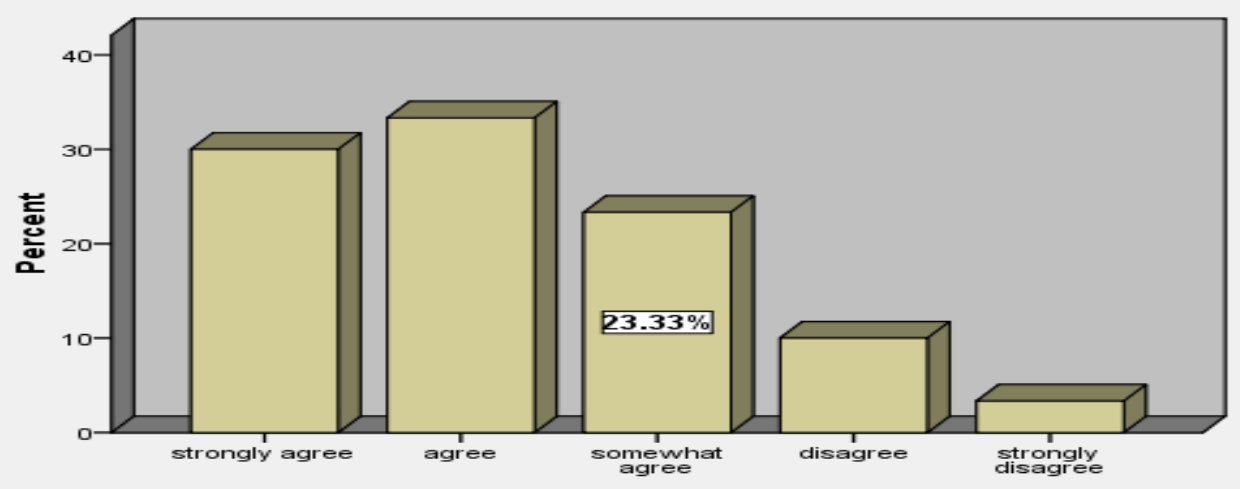

Environmental sustainability policy is active

The hospital is tax compliant in all its tax obligations

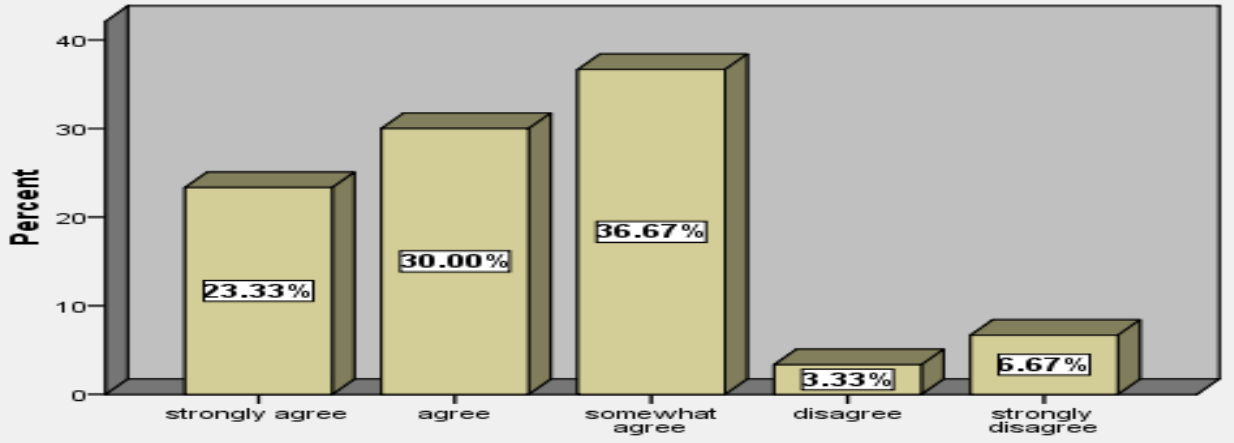

The hospital is tax compliant in all its tax obligations

There is a budget to take care of the needy who cannot pay all hospital bills

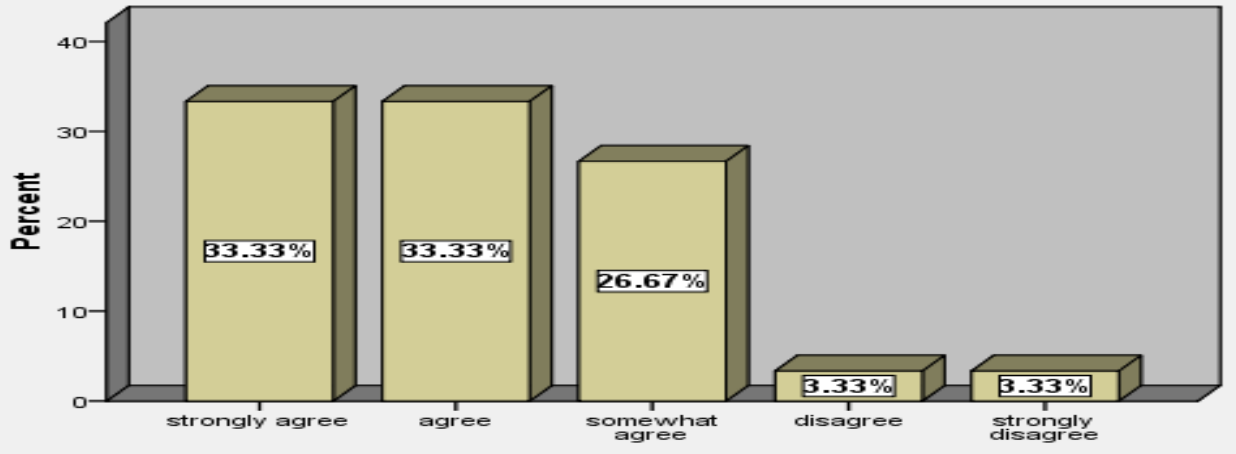

There is a budget to take care of the needy who canno 
There is no discrimination in provision of healthcare services

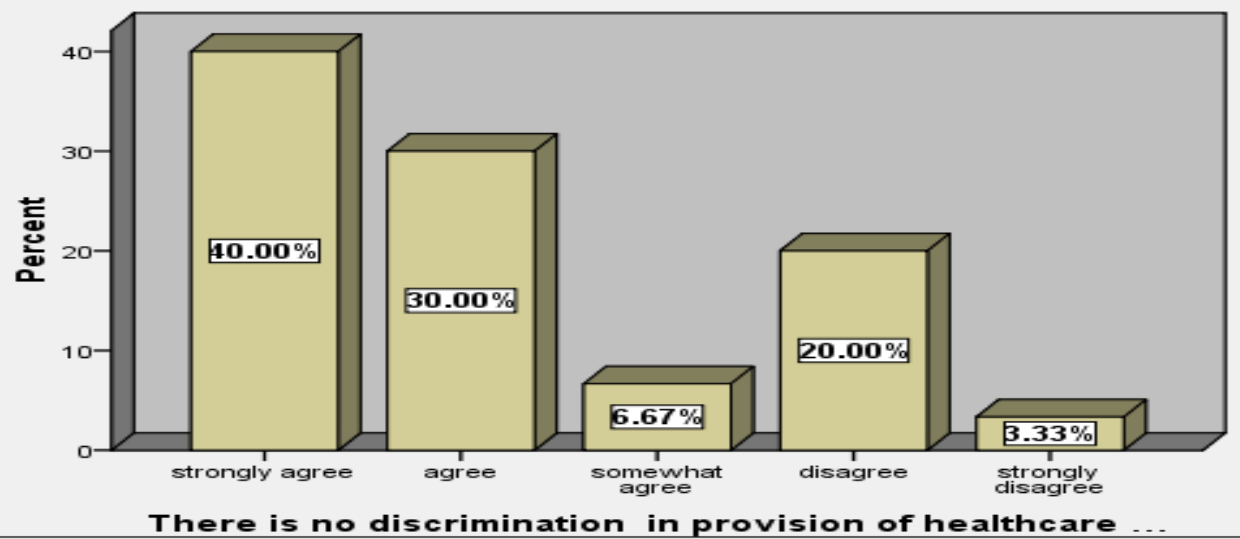

Research objective 3: Examine the effect of corporate identity and clinical communication in service delivery in healthcare

The hospital runs regular informative healthcare programs

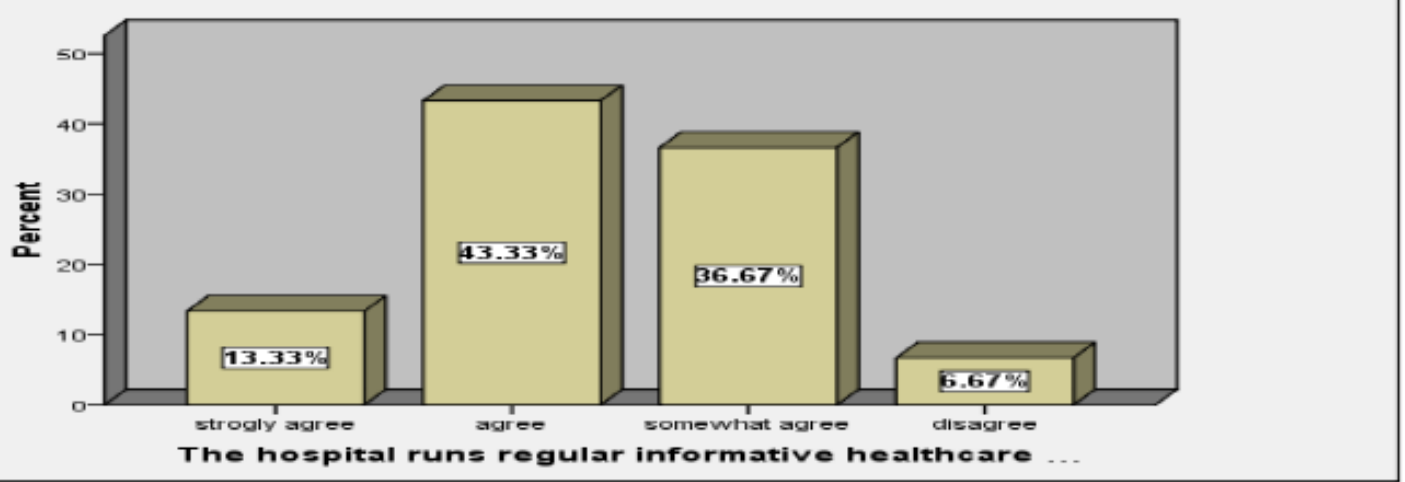

A communication department exists to handle al, public relations matters

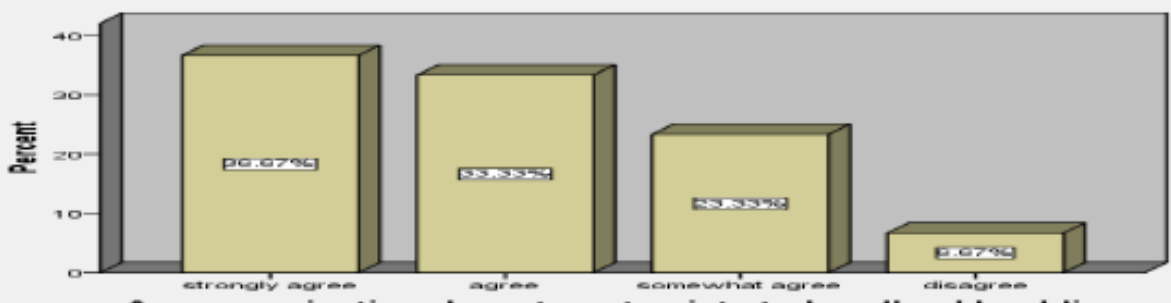

A communication d-partm-ne -xisto to handi- al. publt 


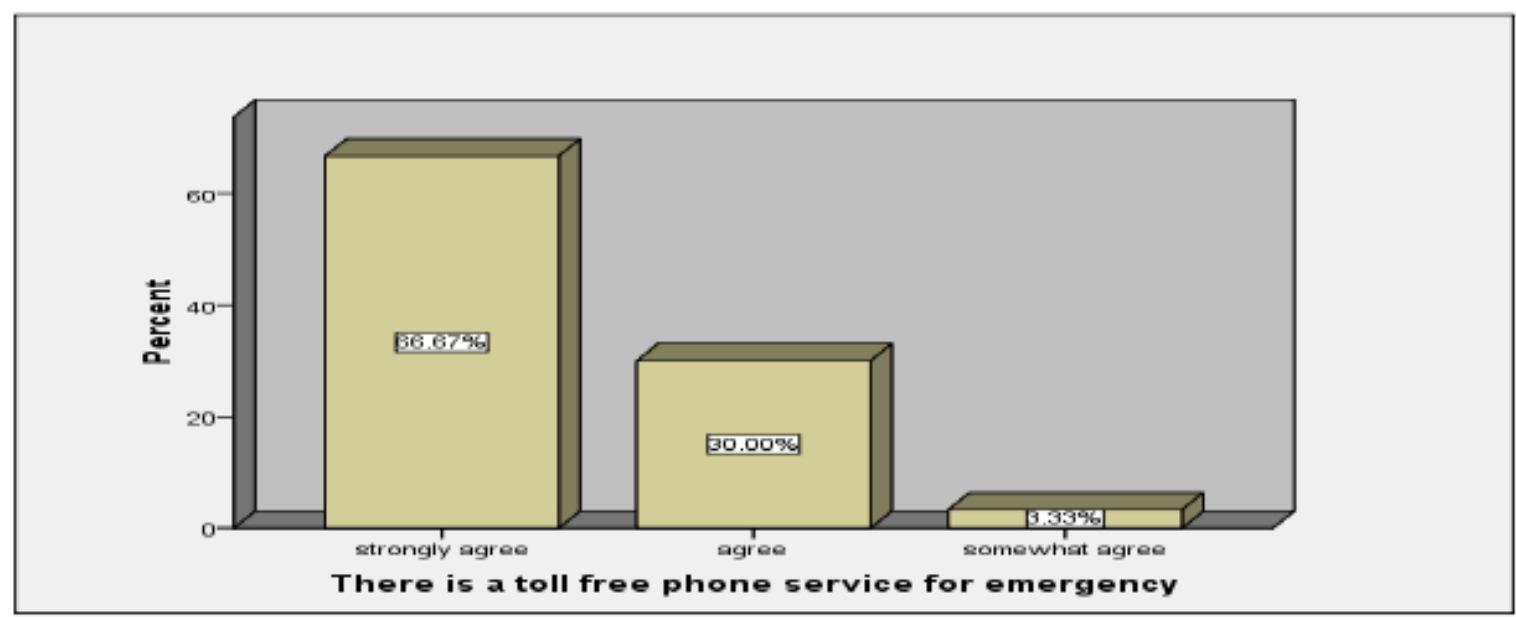

There are sufficient labels to guide customers to the direction of hospital

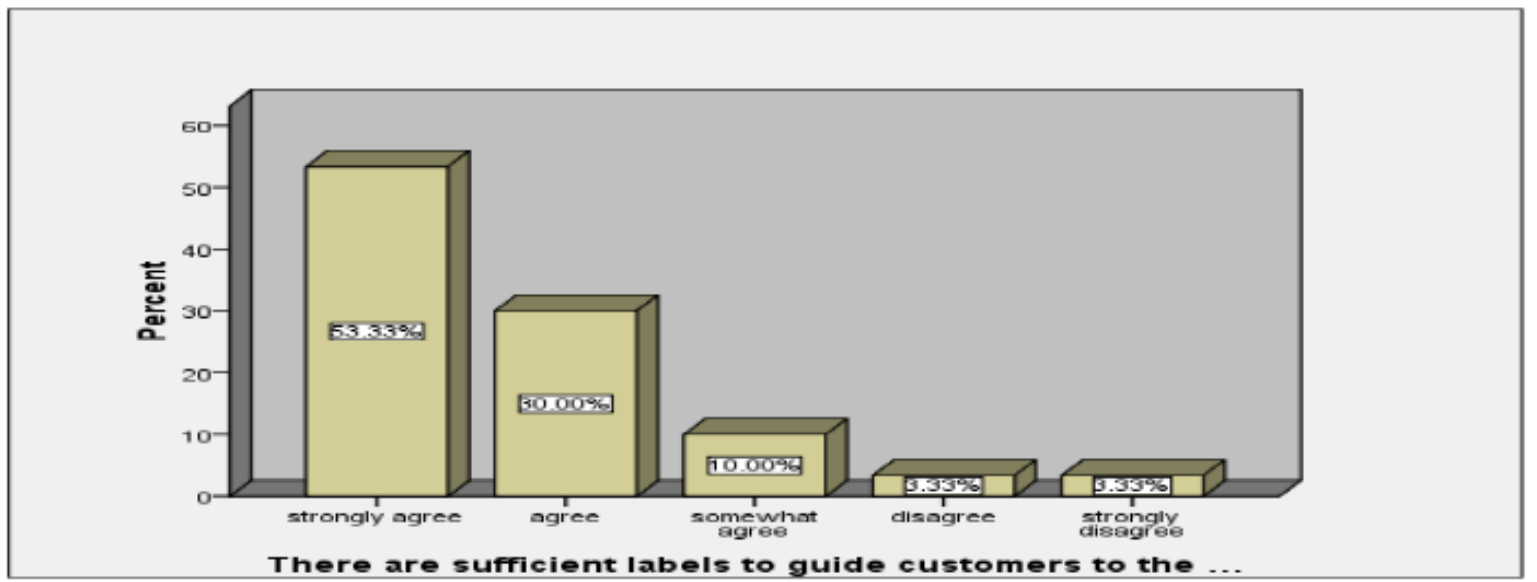

Data analysis and discussion for objective 1: examining effects of corporate planning in clinical governance and service delivery in health care

The results on whether clinical department at GPH is involved in corporate planning indicated that $46.67 \%$ and $26.67 \%$ agree and strongly agree which means $73 \%$ of the respondents indicated that there is clinical department involvement at GPH in corporate planning. Secondly, $66.7 \%$ of the respondents indicated that the clinical services at GPH have sufficient budget. Thirdly, $50 \%$ of the respondents had problems in commenting about bureaucracy at GPH in the realization of funds in clinical services, with only $33.3 \%$ of the respondents agreeing that there is less bureaucracy at GPH in the realization of funds in clinical services. Fourthly, $70 \%$ of the respondents agreed that clinical officers are represented in board of governor's meetings. Lastly, $50 \%$ of the respondents agreed with the point that the board of management reviews ratio and clinicians to patients regularly, however, $30 \%$ of the respondents were very skeptical in answering this.

Data analysis and discussion for objective 2: assessing the role of corporate social responsibility in HIV/AIDS mitigation in service delivery in healthcare

The results under this theme firstly showed that the GPH has been in the forefront of HIV mitigation, $76.6 \%$ of the respondents indicated that the hospital has been in the forefront of HIV mitigation. Again, $66 \%$ of the respondents agreed with the point that the hospital's environmental sustainability policy is active even though $23.3 \%$ of the respondents were very skeptical about the environmental sustainability policy's activeness. Thirdly, $53.3 \%$ of the respondents agreed with the 
point that the hospital is tax compliant in all its tax obligations, however, $36.67 \%$ of the respondents somewhat agreed with this point. Fourthly, $66.66 \%$ of the respondents agreed that there is a budget to take care of the needy that cannot pay for all the hospital bills. On this point $26.67 \%$ of the respondents somewhat agreed to the point that there is a budget to take care of the needy who cannot pay for all the hospital bills. Lastly, under this objective, $70 \%$ of the respondents agreed that there is no discrimination in provision of healthcare services. Interestingly, $23.33 \%$ of the respondents openly disagreed with this point that there is no discrimination in provision of healthcare services.

\section{Data analysis and discussion for objective 3: Examining the effect of corporate identity and clinical communication in service delivery in healthcare}

According to the findings under this theme, $80 \%$ of the respondents agreed with the point that the way the hospital has branded itself have made many potential customers to identify with it. Secondly, $57 \%$ of the respondents indicated that the hospital runs regular informative healthcare programs; however, $37 \%$ of the respondents were very skeptical on the point that the hospital runs regular informative healthcare programs. Thirdly, $70 \%$ of the respondents indicated that a communication department exists to handle all public relations matters though $23 \%$ of the people were showing that the communication department does not clearly handle all the public relations well. Fourthly, $97 \%$ of the respondents indicated that there is a toll-free phone service for emergency at the hospital. Lastly, $83 \%$ of the respondents indicated that there are sufficient labels to guide customers to the direction of hospital.

\section{Conclusion}

Looking at the findings of this study, the effects of corporate planning in clinical governance and service delivery in health care is addressed well though not to the maximum as the above results indicate that bureaucracy in healthcare in the realization of funds in clinical services is a problem. Bureaucracy in healthcare in the realization of funds in clinical services is very critical and essential in achieving a strong impact of corporate planning in clinical governance and service delivery in health care, bureaucracy in healthcare in the realization of funds in clinical services need to be taken seriously too. Again, on the point that the board of management reviews ratio and clinicians to patients regularly, it should be taken seriously in health services for realization of full effects of corporate planning in clinical governance and service delivery in health care, because without the board of management reviews ratio and clinicians to patients being done regularly, it is difficult to acknowledge the effects of corporate planning in clinical governance and service delivery in health care.

Secondly, the study reveals that the role of corporate social responsibility in HIV/AIDS mitigation in service delivery in healthcare is poorly done as shown by the five indicators. Out of the five indicators 3 indicators showed positive results, however, the percentage of respondents who disagreed with the indicators were high that pauses a big question on the way the role of corporate social responsibility in HIV/AIDS mitigation in service delivery in healthcare is being handled. There is a need to critically look into the role of corporate social responsibility in HIV/AIDS mitigation in service delivery in healthcare so that all the five indicators listed should be taken care of. For instance, $23.33 \%$ of the respondents openly disagreed with the point that there is no discrimination in provision of healthcare services; there is no way the role of corporate social responsibility in HIV/AIDS mitigation in service delivery in healthcare can be achieved if discrimination still exists.

Lastly, this recent study has shown that the examination of the effect of corporate identity and clinical communication in service delivery in healthcare has shown that not all the indicators are well satisfied. However, the results revealed that over $90 \%$ of the indicators of the effect of corporate identity and clinical communication in service delivery in healthcare have shown positive direction. This means that the effect of corporate identity and clinical communication in service delivery in healthcare is well observed at the hospital.

\section{Recommendations}

The recommendations are made below following the study findings: 


\section{Recommendations for Objective 1}

i. Bureaucracy in healthcare services in the realization of funds in clinical services must be highly observed as this gives confidence to the people

ii. The board of management in health care services must review ratio and clinicians to patients regularly

Recommendations for Objective 2

i. The environmental sustainability policy in healthcare service must be very active

ii. Hospitals must be tax compliant in all its tax obligations

iii. There must be no discrimination in provision of healthcare services

Recommendations for Objective 3

i. The hospital must run regular informative healthcare programs seriously

ii. The communication department must be functional and well handled in all the public relations

\section{Recommendations for further research}

There is a need to carry out further research on this topic where the sample size and population and or study area must be increased.

\section{References}

[1]. Alexander Berg, (2003). The World Bank: Corporate Group of the World Bank, Washington DC.

[2]. Antoine, F., \& Schmid, H. S. (2006). The Stakeholder Theory.

[3]. Balmer, J. M. T. \& Gray, E. R. (2000). Corporate identity and corporate communications: creating a competitive advantage. Brunel University London and Loyola Marymount University. Vo. 32, No. 7.

[4]. Bernedine, B, B., Slaa, A. M. \& Katamba, D. (2016). Country scan: Netherlands Embassy, Kampala.
[5]. BTC
ANNUAL
REPORT,
(2010).
Available
online: https://www.bocra.org.bw/sites/default/files/documents/BTA\%20Annual\%20Report\%202010.pdf (accessed on $15 / 09 / 2018)$.

[6]. Caramela, S. (2018). What is Corporate Social Responsibility?

[7]. Carrol, A. B. (2008). A history of corporate social responsibility: Concepts and Practices: Oxford University press. London, United Kingdom.

[8]. Cochran, P. L. (2007). The evolution of Corporate Social Responsibility: Indiana University-Purdue University Indianapolis; United States of America.

[9]. Cornforth, Chambers, C. \& Naomi (2010). The role of corporate governance and boards in organizational performance: Cambridge University Press, pp. 99-127; England, United Kingdom.

[10]. Crane, A., Matten, D. \& Spence, L. J. 2012. Corporate social responsibility in global context: University of Bath; United Kingdom.

[11]. Fitzpatrick, M. (2008). Corporate Governance in the Victorian Public Health Sector: School of Management Faculty of Business and Law Victoria University; Melbourne, Australia.

[12]. Freeman, T., Millar, R., Mannion, R. \& Davies, H. (2015). Enacting corporate governance of healthcare safety and quality: a dramaturgy of hospital boards in England: Journal of theoretical social psychology.

[13]. Hilton, CE, (2015). The importance of pretesting questionnaires: a field research example of cognitive pretesting the Exercise referral Quality of Life Scale: (ER-QLS): ' International Journal of Social Research Methodology, vol 20, no. 1, pp. 21-34.

[14]. Health Direct Australia, (n.d). Clinical Governance Framework: Available Online: File:///C:/Users/Hp/Downloads/Clinical-Governance-Framework-2013-V3.Pdf (Accessed On 15/09/2018).

[15]. Iskander, M. R \& Chamlou, N. (2000). The international Bank for Reconstruction and Development/THE WORLD BANK, USA.

[16]. Josiah, J., Themba, G. \& Matenge, T. M. (2016). Corporate Governance in Botswana: Exploring Developments and Compliance; Botswana Journal of Business. Vol 9. No. 1.

[17]. Khan, H. (2001). A Literature Review of Corporate Governance: International Conference on E-business, Management and Economics IPEDR Vol.25 (2011) @ (2011) IACSIT Press, Singapore.

[18]. Kilby, M. (2010-2013). Northern Devon Healthcare NHS Trust: Clinical Governance Support Unit.

[19]. Kumar, H. N. H. \& Pai, U. (2005). A study of CSR for the healthcare of the elderly: International Journal of Medicine and Public Health, Vol. 5, Issue 2. 
[20]. L'huillier, B. (2014). What does "corporate governance" actually mean? International Journal of Business in Society, Prince Mohammad University; Saudi Arabia.

[21]. Macassa, G. (2017). Corporate Social Responsibility and Population Health: Health Science Journal, Mid Sweden University; Sweden.

[22]. Melewar, T.C., Bassett, K. \& Simo es, C. (n.d). The role of communication and visual identity in modern organizations: Available online: Http://People.Unica.It/Ernestinagiudici/Files/2014/03/Melewar-Et-Al.-TheRole-Of-Communication-And-Visual-Identity-In-Modern-Organizations.Pdf (accessed on 02/10/2018).

[23]. Mohamed, R. K. M. \& Nor, C. S. M. (2013). The Relationship between McGregor's X-Y Theory Management Style and Fulfillment of Psychological Contract: A Literature Review: International Journal of Academic Research in Business and Social Sciences. Malaysia, Vol. 3, No. 5.

[24]. Mooketsane, K. S. \& Phirinyane, M. B. (2015). Health governance in Sub-Saharan Africa. Health governance in Sub-Saharan Africa: University of Botswana \& Botswana institute of Development Policy Analysis, Botswana. 15 (3).

[25]. Moroka, K. (2009). Innovative corporate social responsibility in Botswana: The Debswana mining company study case; Contaduría Administration, No. 233, enero-abril 2011: 85-98.

[26]. Moura Leite, R.C. 2011. Historical background of corporate social responsibility: University of Salamanca, Salamanca, Spain.

[27]. Mukhaye, D. (2018). Kyambogo University rolls out free counseling services to neighbors: The Daily Monitor News Paper, Kampala, Uganda. Friday, 21 $1^{\text {st }}$ September. http://www.monitor.co.ug/News/National/Kyambogo-University-rolls-out-free-counselling-services/6883344770068-qpb757/index.html.

[28]. Murphy, C. \& O’Donohoe, S. (2006). Hospital Governance: An Insight from the South East of Ireland; Submitted to the IAFA Annual Conference.

[29]. Okeahalam, C. C. \& Akinboade, O. A. (2003). A review of Corporate Governance in Africa: Literature, Issues and Challenges, Paper prepared for the Global Corporate Governance Forum.

[30]. Raut, S. (n.d). Corporate Governance - Concepts and Issues. Available online: http://www.iodonline.com/Articles/Corporate\%20Governance\%20and\%20Sustainability\%20Concepts\%20Sreet i\%20Raut.pdf (accessed on 10/09/2018).

[31]. Rutitisa, D., Batragab, A., Muiznieceb, L. \& Ritovsa, K. (2012). Management of corporate identity dimensions in the health care: 8th International Strategic Management Conference; Latvia b University of Latvia, Latvia- 2012 Published by Elsevier Ltd.

[32]. Selvam, P. (2016). A corporate social responsibility: Shanlax international Journal of Arts, Science and Humanities; Madurai Kamaraj University - Tamil Nadu, India Vol. 4, Issue 2.

[33]. Staniland, K. M. (2007). Clinical Governance and Nursing - a Sociological Analysis: Institute for Social, Cultural and Policy Research (ISCPR) School of Nursing University of Salford, Salford, UK.

[34]. USAID from the American People, (2015). African Strategies for Healt.

[35]. Wesley, C. L. (2010). The Impact of Stewardship on Firm Performance: A Family Ownership and Internal Governance Perspective: Dissertation.

[36]. World Health Organization, Communication for Health: Brand and corporate identity. http://www.who.int/communicating-for-health/functions/branding/en/.

[37]. Youssef, M. T. (n.d). Corporate Governance an Overview - Around the Globe (1), Grant Thornton Egypt. 